AperTO - Archivio Istituzionale Open Access dell'Università di Torino

\title{
Impact on prognosis of periprocedural myocardial infarction after percutaneous coronary intervention.
}

\section{This is the author's manuscript}

Original Citation:

Availability:

This version is available http://hdl.handle.net/2318/149471

since

Published version:

DOI:10.1111/joic.12143

Terms of use:

Open Access

Anyone can freely access the full text of works made available as "Open Access". Works made available under a Creative Commons license can be used according to the terms and conditions of said license. Use of all other works requires consent of the right holder (author or publisher) if not exempted from copyright protection by the applicable law. 


\section{(6) \\ UNIVERSITÀ DEGLI STUDI DI TORINO}

This is an author version of the contribution published on:

Questa è la versione dell'autore dell'opera:

J Interv Cardiol. 2014 Oct; 27(5):482-90. doi: 10.1111/joic.12143

The definitive version is available at:

La versione definitiva è disponibile alla URL:

http://onlinelibrary.wiley.com/doi/10.1111/joic.12143/abstract 


\section{ABSTRACT}

Introduction. Different definitions of periprocedural myocardial infarction (MI) after Percutaneous Coronary Intervention (PCI) have been provided, but their impact on prognosis remains to be determined.

Methods. Procedural data from consecutive patients undergoing PCI from 2009 to 2011 were revised to adjudicate diagnosis of periprocedural MI according to CK-MB increase ( $>3 \times \mathrm{URL}$ and $>5 \times$ URL), to troponin increase $\left(>3 \times 99^{\text {th }}\right.$ percentile URL and $>5 \times 99^{\text {th }}$ percentile URL) and to recent 2012 Task and SCAI definitions. MACE (Major Adverse Cardiovascular Events) was the primary end point.

Results. 712 patients were enrolled: after 771 days, 115 (16.7\%) patients experienced MACE. 190 patients were diagnosed a periprocedural MI defined as elevation of troponin $>5 \times 99^{\text {th }}$ percentile of URL. When adjudicating 2012 Task Force definition on these patients, 46 were excluded and 1.4\% of them experienced a MACE and $0.3 \%$ died, while among 144 with periprocedural MI, $2.9 \%$ reported a MACE and $1.3 \%$ died. After appraisal of SCAI definition, 176 patients were excluded, $3.8 \%$ of them with a MACE and $1.4 \%$ died, and for those with periprocedural MI, $0.5 \%$ experienced a MACE and $0.1 \%$ died. Similar low performance was appraised after reclassification of patients from more than 3 of upper limit of CK-MB and of troponin. At multivariate analysis, none of these definitions related to adverse events.

Conclusion. Periprocedural MI represents a frequent complication for patients undergoing PCI. Al present definitions share a still not satisfactory discrimination between patients with and without adverse events at follow up, stressing the need for more accurate definitions.

Keywords: percutaneous coronary intervention; periprocedural myocardial infarction; cardiac biomarkers. 


\section{INTRODUCTION}

Cardiac biomarkers elevation may often occur after percutaneous coronary interventions (PCI) due to interplay of several mechanisms like coronary occlusion or dissection, distal embolization, slowflow or no-reflow ${ }^{1},{ }^{2}$. The term PCI-related myocardial infarction has been introduced to refer to this pathological finding but many different cut-offs and biomarkers (i.e. CK.MB and Troponins) have been used to define this entity, resulting in a complex and variegated picture. Moreover, while

originally associated with a worsened outcome ${ }^{3,4}$, many recent reports have failed to show a consistent prognostic value related to PCI-related myocardial infarction, especially when Troponins were used in place of $\mathrm{CK}-\mathrm{MB}^{5,6}$.

As a consequence, to date, no definite conclusions can be drawn about the clinical relevance of procedural-related increases in cardiac biomarkers ${ }^{7}$. In the attempt to address these issues, two consensus papers have been recently released to provide unanimous directives on this topic. First, the ESC, ACCF, AHA and WHF Task Force for the Third universal definition of myocardial infarction, arbitrarily restricted the diagnosis of myocardial infarction with PCI (the type 4a MI, from now on "2012 Task Force definition") only to those patients with symptoms or instrumental signs of myocardial ischemia associated with the increase in Troponin ${ }^{8}$. More recently, the Society for Cardiovascular Angiography and Interventions (SCAI), formulated new definitions selecting biomarkers cutoffs clearly associated with a worsened prognosis after literature review (referred to as "SCAI definition" from now on $)^{9}$. However, since a clinical validation of these formulated criteria is lacking, we conducted this study with the aim to assess the prognostic value of new definitions and to compare them with the older criteria. 


\section{METHODS}

All consecutive patients undergoing PCI both elective both for Unstable Angina (UA) in our Center (defined as index hospitalization) between January 2009 and January 2011 (Division of Cardiology, University of Turin) were included and recorded in the electronic database of our Institution (Azienda Ospedaliera Città della Salute e della Scienza). Patients with myocardial infarction were excluded. The manuscript was written according to Strobe Statement ${ }^{10}$.

Baseline and interventional features were analyzed through revisiting medical records about hospitalizations for PCIs registered on dedicated Medical Records Process Management ${ }^{11}$. All variables were defined according to definitions of Euro Heart PCI score ${ }^{12}$ or, if not reported there, to international guidelines. Patients were deemed to have valvular disease if at least of moderate entity. EuroHeartPCI score was retrospectively elaborated ${ }^{13}$. In patients presenting with unstable angina, pre-procedural increases of Troponin and CK-MB were ruled out performing at least 3 measurements over an interval time of at least 12 hours from last symptoms appearance. Heparin was the anticoagulant of choise during PCI. Patients were treated according to current guidelines at discharge; double antiplatelet therapy (DAT) was administered for at least 1 month in the case of bare-metal stents implantation and for at least 12 months in the case of drug-eluting stents implantation.

Periprocedural myocardial infarction was defined according to previously published criteria as: a CK-MB increase $>3 \times$ URL; a CK-MB increase $>5 \times$ URL $^{14}$; a Troponin increase $>3 \times 99^{\text {th }}$ percentile URL ${ }^{15}$; and a Troponin increase $>5 \times 99^{\text {th }}$ percentile URL ${ }^{16}$. Moreover, according to the 2012 Task Force definition, as a Troponin increase $>5 \times 99^{\text {th }}$ percentile URL associated with at least one among prolonged chest pain ( $\geq 20 \mathrm{~min})$, ischemic ST changes and/or Q waves, angiographic evidence of a flow limiting complication or imaging evidence of new loss of viable myocardium or 
new regional wall motion abnormality $^{8}$; and, according to the SCAI definition, as a CK-MB increase $\geq 10 \times$ URL, or $\geq 5 \times$ URL with new pathologic Q-waves in $\geq 2$ contiguous leads or new persistent LBBB, or a cTn increase $\geq 70 \times$ URL, or $\geq 35 \times$ URL with new pathologic Q-waves in $\geq 2$ contiguous leads or new persistent $\mathrm{LBBB}^{9}$. Increases of myocardial biomarkers were due to happen within 48 hours after PCI.

MACE (that is death, myocardial infarction and repeated revascularization) after a mean follow up of at least 365 days were the primary end points, while its single components the secondary ones. Data about both short term and long term outcomes derived from AURA (Anagrafe Unitaria Regionale Assistiti) ${ }^{17}$, an institutional database recording all hospitalizations in Piedmont. Data about long term outcomes were collected by telephonic follow up were medical records were not available.

\section{Statistical analysis}

Continuous variables are expressed as mean \pm standard deviation and were compared with ANOVA. Categorical variables are presented as counts and percentage and were compared with the chi-squared test. Statistical significance was set at the two-tailed 0.05 level. According to number of events for variables appraised and for differences in follow up ${ }^{18,19}$, six different models of Cox proportional hazard analysis were performed for MACE at long-term follow-up, including each different PCI-related myocardial infarction, age, gender, ejection fraction, renal creatinine clearance and all variables with differences at univariate analysis $(\mathrm{p}<0.05)$. For each model accuracy was evaluated with Area under the Curve (AUC), calibration with Hosmer-lemeshow test, the proportion of variance in the dependent variable associated with the predictor (independent) variables with and loss of information through Akaike information criterion. Computations were performed with SPSS 21.0 (IBM Corporation, Armonk, NY, USA). 


\section{RESULTS}

Study population

A total of 712 patients were included in the present study, 318 (44.7\%) of whom with a diagnosis of unstable angina. Baseline characteristics are shown in Table 1. According to the different definitions, PCI-related myocardial infarction was found, respectively, in $48(6.7 \%$, CK-MB >3 x URL MI), 22 (3.1\%, CK-MB >5 x URL MI), 254 (35.7\%, Tn >3 x 99 ${ }^{\text {th }}$ percentile MI), 190 (26.7\%, Tn $>5 \times 99^{\text {th }}$ percentile MI), $144(20.2 \%, 2012$ Task Force definition) and 14 (2.0\%, SCAI definition). General characteristics of these subgroups are shown in Table 1. DAT wasn't administered to 12 patients, who were treated with a single antiplatelet drug; of them, 2 (20\%) experienced MACE (both rePCI).

Study end-points

After a mean follow up of $771 \pm 332$ days, overall $115(16.7 \%)$ patients experienced MACE. In detail, $35(5.1 \%)$ died (24 [70.6\%] to a CV disease), 18 (2.6\%) experienced myocardial infarction, $83(12.0 \%)$ underwent recurrent PCI and 3 (0.4\%) CABG (Table 2). At univariate analysis, age, creatinine clearance, EF, diabetes, valvular disease, increased levels of Troponin before the procedure, LM disease, CTO and Euro Heart PCI score were significantly associated with MACE at follow up. Table 3 shows univariate predictors and respective p-values for MACE and its single components. PCI-related myocardial infarction didn't relate to MACE or to its single components at follow-up. Six different multivariate models, one for each PCI-related myocardial infarction definition, were conducted by Cox multivariate analysis to identify what parameters independently predicted MACE at follow up (Table 4). Other than PCI-related myocardial infarction, all variables significantly related to MACE at univariate analysis ( $\mathrm{p}$ value $<0.05$ ) were included (age, creatinine clearance, EF, diabetes, valvular disease, pre-procedural Troponin increased values, LM disease, CTO and Euro Heart PCI score). Valvular heart disease (OR 2.0 95\% CI 1.1-3.6, p=0.02) and baseline elevated Troponin levels before angioplasty (OR $0.395 \%$ CI 0.1-0.8, p=0.020) emerged as 
the lone independent predictors of MACE at follow up. Among the different definitions of PCIrelated myocardial infarction, only the SCAI definition showed a trend towards predicting MACE (OR $2.895 \%$ CI 0.9-9.1, p=0.08).

Comparison among definitions

We compared the different subgroups as determined by each definition. As shown in figure 1, some definitions (those based on CK-MB and the SCAI definition) include a small number of patients (respectively, 48, 22, 14, experiencing respectively 8, 3, 4 MACE), with the consequence of excluding most of the patients experiencing MACE (respectively, 107, 112, 111). The SCAI definition, for example, is able to identify a subset of patients with almost 1 out of 3 chances of experiencing MACE, but at the expenses of excluding more than the 95\% of the overall MACE. Conversely, the 2012 Task Force definition includes a greater number of patients (respectively 254, 190, 144) without being able to identify those with an increased risk. The subgroup identified by the latter definition is formed by a higher number of patients with unfavorable events as compared by the SCAI definition, but the rate of MACE was lower in this sample than in the SCAI group and than in the overall population, resulting in a poor performance at multivariate analysis (OR 0.855 95\% CI 0.5-1.5, p 0.58). Compared to the definition of $\mathrm{Tn}>5 \times 99^{\text {th }} \mathrm{MI}$, the 2012 Task Force definition excludes a subgroup of patients experiencing a rate of MACE higher than those included. As seen in Table 5, for each model accuracy was very low for MACE, all with an acceptable calibration but with low R2 of Nagelkerke and with a high loss of information according to Akaike information criterion. 


\section{DISCUSSION}

The main finding of our study is that all different definitions of PCI related myocardial infarctions failed to accurately detect adverse events after PCI, with similar rates of MACE and of death for those with and without MI in a single-center, real-life cohort, of patients, after a follow up of more than 2 years. Peri-procedural MI has been longtime considered equivalent to spontaneous MI, since the amount of biomarkers increase in the two events is often comparable. These two myocardial injuries, however, are clearly different events, with marked pathologic and prognostic differences $^{20}{ }^{21}$. Spontaneous MI represents the expression of the occlusion of a coronary artery, while PCI-related MI is an event related to the reopening of a diseased vessel. In two recent analysis, only spontaneous MI conferred an increased risk of death at long term follow up ${ }^{20,21}$. Different physiopathologies may exist even among PCI-related MI, as only unsuccessful procedures have been shown to relate to an adverse outcome as opposed to successful procedures, despite similar amounts of biomarkers increases ${ }^{22}$. Variability in rates of unsuccessful procedures in different cath labs may contribute to justify the inconsistent results on PCI-related myocardial infarction and it could be affected by the quality of care of the different centers performing PCI. Highly variable rates of periprocedural MI are described in literature, due to differences in definitions adopted, population characteristics and type and techniques pf PCI performed; thebrates found in our study are similar to those found in other, larger, series ${ }^{23,24,25}$.

Any definition tested in our study proved unable to discriminate from the overall population those patients encountering a substantially increased amount of unfavorable events at follow up, even when using the newly introduced definitions from 2012 Task Force ${ }^{8}$ and from SCAI ${ }^{9}$. Each definition includes a too large or a too limited number of patients, with opposite consequences. In the first case, it is not possible to appraise patients at increased risk, and, in the second, too many patients experiencing considerable rates of events were excluded. Reclassification from one definition to another did not improve accuracy, with comparable rates of death and MACE in patients with and without different diagnosis of periprocedural MI. Only the SCAI definition 
showed a trend towards a relationship with MACE, but it included only a reduced number of, excluding in the process the majority of patients experiencing events. Similar results have emerged in recent years from several studies ${ }^{5,6,21,23}$ which described the post-procedural increases in cardiac biomarkers as epiphenomenons of a more severe underlying atherosclerotic burden, of an increased prevalence of three-vessel disease and/or left main artery disease and of more complex procedures, all factors per se explaining an increased risk of unfavorable events. Further indices of the inability of the 2012 Task Force definition to provide any additional prognostic value come from a recent report by Baker et al. ${ }^{24}$, as this definition didn't related to death or MI after 1 year of follow up. Interestingly, this study showed a considerably lower rate of periprocedural MI defined according to the 2012 Task Force $(2.1 \%)$ as compared to ours, even in the presence of very similar rates of periprocedural MI defined as $\mathrm{Tn}>3 \times 99^{\text {th }}$ percentile MI $(31.9 \%)$, and it demonstrated a better performance of both definitions at ROC analysis. The greater sample size, the exclusion of UA patients, the different end-points and the longer time span of enrolment in the study by Baker et al. could explain these differences. Events in the strudy by Baker et al. were assessed after a shorter follow up (1 years, > 2 years in our report), a noticeable difference that could explain the betterperformance at ROC analysis, since the clinical influence of periprocedural MI appear stronger in the early phases after PCI. Indeed, while long-term prognostic value of biomarkers elevations is increasingly doubted, some results recently converged showing a relationship between post-procedural MI and 30-days outcome, a finding underlining how PCI related myocardial infarction identifies a subset of patients deserving a more strict monitoring in the early phases following revascularization ${ }^{5,24}$.

Based on the comparison between our results and those by Baker et al, it has to be evaluated if adding clinical parameters to biomarkers levels dosing in the appraisal of periprocedural Mi may lead to greater variability in its adjudication. Concerning SCAI definition ${ }^{9}$, to our knowledgr to date no other studies attempted its validation in a clinical setting. 
The low performance of all the definition casts doubt on the actual value and usefulness of cardiac biomarkers in the assessment of PCI-related myocardial damage ${ }^{7}$. Other parameters with a known strong prognostic value, particularly variations in left ventricular global function and regional wall motion, should be tested in this setting. Only a limited portion of these patients has been shown to develop lesions detectable by late-gadolinium enhancement at magnetic resonance imaging ${ }^{24}$, however with a still unknown impact on prognosis. Moreover, more data should be reported about patients presenting with multivessel coronary artery disease ${ }^{25}$, with particular coronary anatomy ${ }^{26,27}$ while, recently, a FFR (Fractional Flow Reserve) based PCI has demonstrated to reduce PMI ${ }^{28,29}$

Controversial results have emerged primarily from studies using Troponin (I or T) as the marker of choice, while with CK-MB has generally shown a greater agreement towards a prognostic value of periprocedural myocardial infarction, even if consistent results were shown only for markedly

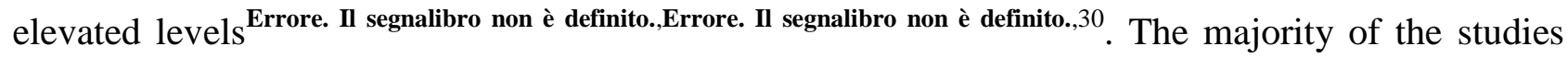
showing an unfavorable outcome with elevations in CK-MB included a high percentage of patients with ACS and, many post-procedural increases in CK-MB were actually pre-procedural ${ }^{7,31}$. More recent results from a population of patients with stable or unstable angina showed indeed no prognostic value for any CK-MB elevation (SPIRIT-IV trial, results provided in the SCAI consensus paper $)^{32}$. In fact, either for CK-MB and Troponin, it has been clearly demonstrated the prognostic value of pre-procedural elevation in cardiac biomarkers, probably overcoming that of post -procedural elevations ${ }^{5,33,34}$, a result confirmed also by our present data. According to our data, the main criteria failed to provide substantial indications on the long-term outcome of the patients affected. However, given the limited number of events occurring in our population, definite conclusions on the actual prognostic value of PCI related MI should be corroborated by adequately powered study. 
Differences in physiopathology may explain the reports questioning if PCI-related MI actually significantly worsens the long-term outcome. Prasad and colleagues showed that myocardial necrosis after PCI didn't predict long-term outcome ${ }^{5}$, as only pre-procedural elevations in myocardial biomarkers did. Similar conclusions were also drawn by Cavallini et al., even if their analysis excluded patients with elevations in $\mathrm{CK}-\mathrm{MB}^{6}$. On the wake of these experiences, many authors started to question the clinical relevance of this finding and to doubt the need to monitor cardiac biomarkers after each procedure ${ }^{7,31}$. Moreover, the use of many different criteria to define PCI-related MI limited the interpretation of the results from different studies contributing to the confusion surrounding this topic. The publication of a new definition of the "MI type 4a" by 2012 Task Force, with the aim to include in this definition only "clinically relevant events" 35 tried to answer these questions, but being related, as stated by the authors, solely on arbitrarily chosen criteria. The consensus document released by the SCAI, in contrast, provided new criteria for the diagnosis of PCI related myocardial infarction that, pending a careful review of literature, would confer a prognostic value ${ }^{9}$.

\section{Study limitations}

Due to the retrospective nature of our study, a confirmation on a prospectic cohort of these results is desirable, especially of the new definitions by 2012 Task Force ${ }^{8}$ and SCAI $^{9}$. Given limited statistical power of the study, conclusive inferences on the prognostic value of periprocedural MI should be avoided; the main finding of the present study is the overall poor performance of different definitions in selecting patients at increased risk. Moreover lack of data about pharmacological therapy, as beta blockers or statin, may limit the accuracy of the present data. 


\section{REFERENCES}

${ }^{1}$ Herrmann J. Peri-procedural myocardial injury: 2005 update. Eur Heart J 2005;26:2493-519

${ }^{2}$ D'Ascenzo F, Moretti C, Omedè P, Cerrato E, Cavallero E, Er F, Presutti DG, Colombo F, Crimi G, Conrotto F, Dinicolantonio JJ, Chen S, Prasad A, Biondi Zoccai G, Gaita F. Cardiac remote ischaemic preconditioning reduces periprocedural myocardial infarction for patients undergoing percutaneous coronary interventions: a meta-analysis of randomised clinical trials. EuroIntervention 2014;9(12):1463-71

${ }^{3}$ Califf RM, Abdelmeguid AE, Kuntz RE, Popma JJ, Davidson CJ, Cohen EA, Kleiman

NS, Mahaffey KW, Topol EJ, Pepine CJ, Lipicky RJ, Granger CB, Harrington RA, Tardiff BE, Crenshaw BS, Bauman RP, Zuckerman BD, Chaitman BR, Bittl JA, Ohman

EM. Myonecrosis after revascularization procedures. J Am Coll Cardiol 1998;31(2):241-51

${ }^{4}$ Testa L, Van Gaal WJ, Biondi Zoccai G, Agostoni P, Latini RA, Bedogni F, Porto I, Banning AP. Myocardial infarction after percutaneous coronary intervention: a meta-analysis of troponin elevation applying the new universal definition. QJM 2009;102(6):369-78

${ }^{5}$ Prasad A, Rihal CS, Lennon RJ, Singh M, Jaffe AS, Holmes DR Jr. Significance of periprocedural myonecrosis on outcomes after percutaneous coronary intervention: an analysis of preintervention and post- intervention troponin T levels in 5487 patients. Circ Cardiovasc Interv 2008;1:10-9

${ }^{6}$ Cavallini C, Verdecchia P, Savonitto S, Arraiz G, Violini R, Olivari Z, Rubartelli P, De Servi S, Plebani M, Steffenino G, Sbarzaglia P, Ardissino D; Italian Atherosclerosis, Thrombosis and Vascular Biology and Society for Invasive Cardiology-GISE Investigators. Prognostic value of isolated troponin I elevation after percutaneous coronary intervention. Circ Cardiovasc Interv 2010;3(5):431-5

${ }^{7}$ Jaffe AS, Apple FS, Lindahl B, Mueller C, Katus HA. Why all the struggle about CK-MB and PCI? Eur Heart J 2012;33:1046-8. 
${ }^{8}$ Thygesen K, Alpert JS, Jaffe AS, Simoons ML, Chaitman BR, White HD; Writing Group on the Joint ESC/ACCF/AHA/WHF Task Force for the Universal Definition of Myocardial Infarction. Third universal definition of myocardial infarction. Eur Heart J 2012;33(20):2551-67

${ }^{9}$ Moussa ID, Klein LW, Shah B, Mehran R, Mack MJ, Brilakis ES, Reilly JP, Zoghbi G, Holper E, Stone GW. Consideration of a new definition of clinically relevant myocardial infarction after coronary revascularization: An expert consensus document from the society for cardiovascular angiography and interventions (SCAI). Catheter Cardiovasc Interv 2014;83(1):27-36

${ }^{10}$ von Elm E, Altman DG, Egger M, Pocock SJ, Gøtzsche PC, Vandenbroucke JP; STROBE Initiative. The Strengthening the Reporting of Observational Studies in Epidemiology (STROBE) statement: guidelines for reporting observational studies. J Clin Epidemiol 2008;61(4):344-9

${ }^{11}$ http://www.normadec.it/htorino/info.asp

${ }^{12}$ http://www.escardio.org/Policy/Documents/CARDS-dataset-PCI-1104.pdf

${ }^{13}$ de Mulder M, Gitt A, van Domburg R, Hochadel M, Seabra-Gomes R, Serruys PW, Silber S, Weidinger F, Wijns W, Zeymer U, Hamm C, Boersma E. EuroHeart score for the evaluation of in-hospital mortality in patients undergoing percutaneous coronary intervention. Eur Heart J 2011;32(11):1398-408

${ }^{14}$ Ellis SG, Chew D, Chan A, Whitlow PL, Schneider JP, Topol EJ. Death following creatine kinase-MB elevation after coronary intervention: identification of an early risk period: importance of creatine kinase-MB level, completeness of revascularization, ventricular function, and probable benefit of statin therapy. Circulation 2002;106:1205-10

${ }^{15}$ Thygesen K, Alpert JS, White HD. Joint ESC/ACCF/AHA/WHF task force for the redefinition of myocardial infarction. Universal definition of myocardial infarction. Eur Heart J 2007;28:2525-38 ${ }^{16}$ American College of Cardiology/American Heart Association Task Force on Practice Guidelines; ACC/AHA/SCAI Writing Committee to Update 2001 Guidelines for Percutaneous Coronary Intervention. ACC/AHA/SCAI 2005 guideline update for percutaneous coronary intervention: a 
report of the American College of Cardiology/American Heart Association Task Force on Practice Guidelines (ACC/AHA/SCAI Writing Committee to Update 2001 Guidelines for Percutaneous Coronary Intervention). Circulation. 2006;113(7):e166-286

${ }^{17}$ http://www.csipiemonte.it/cms/portfolio/salute/aura.html

${ }^{18}$ Biondi-Zoccai G, Romagnoli E, Agostoni P, Capodanno D, Castagno D, D'Ascenzo F, Sangiorgi G, Modena MG. Are propensity scores really superior to standard multivariable analysis? Contemp Clin Trials 2011;32(5):731-40

${ }^{19}$ D'Ascenzo F, Cavallero E, Biondi-Zoccai G, Moretti C, Omedè P, Bollati M, Castagno D, Modena MG, Gaita F, Sheiban I. Use and misuse of multivariable approaches in interventional cardiology studies on drug-eluting stents: a systematic review. J Interv Cardiol 2012; 25(6):611-21. ${ }^{20}$ Prasad A, Gersh BJ, Bertrand ME, Lincoff AM, Moses JW, Ohman EM, White HD, Pocock SJ, McLaurin BT, Cox DA, Lansky AJ, Mehran R, Stone GW. Prognostic significance of periprocedural versus spontaneously occurring myocardial infarction after percutaneous coronary intervention in patients with acute coronary syndromes: an analysis from the ACUITY (Acute Catheterization and Urgent Intervention Triage Strategy) trial. J Am Coll Cardiol 2009;54(5):47786

${ }^{21}$ Damman P, Wallentin L, Fox KA, Windhausen F, Hirsch A, Clayton T, Pocock SJ, Lagerqvist B, Tijssen JG, de Winter RJ. Long-term cardiovascular mortality after procedure-related or spontaneous myocardial infarction in patients with non-ST-segment elevation acute coronary syndrome: a collaborative analysis of individual patient data from the FRISC II, ICTUS, and RITA3 trials (FIR). Circulation 2012;125(4):568-76

22 Jeremias A, Baim DS, Ho KK, Chauhan M, Carrozza JP Jr, Cohen DJ, Popma JJ, Kuntz RE, Cutlip DE. Differential mortality risk of postprocedural creatine kinase-MB elevation following successful versus unsuccessful stent procedures. J Am Coll Cardiol 2004;44(6):1210-4

${ }^{23}$ De Labriolle A, Lemesle G, Bonello L, Syed AI, Collins SD, Ben-Dor I, Pinto Slottow TL, Xue 
Z, Torguson R, Suddath WO, Satler LF, Kent KM, Pichard AD, Lindsay J, Waksman R. Prognostic significance of small troponin I rise after a successful elective percutaneous coronary intervention of a native artery. Am J Cardiol 2009;103(5):639-45

${ }^{24}$ Lim CC, van Gaal WJ, Testa L, Cuculi F, Arnold JR, Karamitsos T, Francis JM, Petersen SE, Digby JE, Westaby S, Antoniades C, Kharbanda RK, Burrell LM, Neubauer S, Banning AP. With the "universal definition," measurement of creatine kinase-myocardial band rather than troponin allows more accurate diagnosis of periprocedural necrosis and infarction after coronary intervention. J Am Coll Cardiol 2011;57(6):653-61

${ }^{25}$ D'Ascenzo, Presutti DG, Picardi E, Moretti C, Omedè P, Sciuto F, Novara M, Yan AT, Goodman S, Mahajan N, Kosuge M, Palazzuoli A, Jong GP, Isma'eel H, Budoff MJ, Rubinshtein R, Gewirtz H, Reed MJ, Theroux P, Biondi-Zoccai G, Modena MG, Sheiban I, Gaita F. Prevalence and noninvasive predictors of left main or three-vessel coronary disease: evidence from a collaborative international meta-analysis including 22740 patients. Heart 2012;98(12):914-9.

${ }^{26}$ Basavarajaiah S, Latib A, Shannon J, Naganuma T, Sticchi A, Bertoldi L, Costopoulos C, Figini F, Carlino M, Chieffo A, Montorfano M, Colombo A. Drug-Eluting Balloon in the Treatment of InStent Restenosis and Diffuse Coronary Artery Disease: Real-World Experience from Our Registry. J Interv Cardiol 2014; doi: 10.1111/joic.12129 [Epub ahead of print] ${ }^{27}$ Quadri G, D'ascenzo F, Bollati M, Moretti C, Omedé P, Sciuto F, Gonella A, Pullara A, Longo G, Cerrato E, Colombo F, Presutti DG, Colaci C, De Simone V, Di Cuia M, Giusto F, Reitano C, Zoccai GB, Sheiban I, Gaita F. Diffuse coronary disease: short- and long-term outcome after percutaneous coronary intervention. Acta Cardiol 2013;68(2):151-60.

${ }^{28}$ Park SJ1, Ahn JM, Park GM, Cho YR, Lee JY, Kim WJ, Han S, Kang SJ, Park DW, Lee SW, Kim YH, Lee CW, Mintz GS, Park SW. Trends in the outcomes of percutaneous coronary intervention with the routine incorporation of fractional flow reserve in real practice._Eur Heart $J$ 2013;34(43):3353-61. 
${ }^{29}$ Novara M, D'Ascenzo F, Gonella A, Bollati M, Biondi-Zoccai G, Moretti C, Omedè P, Sciuto F, Sheiban I, Gaita F. Changing of SYNTAX score performing fractional flow reserve in multivessel coronary artery disease. J Cardiovasc Med (Hagerstown) 2012;13(6):368-75.

${ }^{30}$ Lindsey JB, Kennedy KF, Stolker JM, Gilchrist IC, Mukherjee D, Marso SP, Pencina MJ, Kleiman NS, Cohen DJ. Prognostic implications of creatin kinase-MB elevation after percutaneous coronary intervention: results from the Evaluation of Drug-Eluting Stents and Ischemic Events (EVENT) registry. Circ Cardiovasc Interv 2011;4(5):474-80

31 Prasad A, Herrmann J. Myocardial infarction due to percutaneous coronary intervention. N Engl J Med 2011;364(5):453-64

${ }^{32}$ Stone GW, Rizvi A, Newman W, Mastali K, Wang JC, Caputo R, Doostzadeh J, Cao S, Simonton CA, Sudhir K, Lansky AJ, Cutlip DE, Kereiakes DJ; SPIRIT IV Investigators. Everolimus-eluting versus paclitaxel-eluting stents in coronary artery disease. $N$ Engl $\mathrm{J} \mathrm{Med}$ 2010;362(18):1663-74

33 Jeremias A, Kleiman NS, Nassif D, Hsieh WH, Pencina M, Maresh K, Parikh M,_Cutlip DE, Waksman R, Goldberg S, Berger PB, Cohen DJ; Evaluation of Drug Eluting_Stents and Ischemic Events (EVENT) Registry Investigators. Prevalence and prognostic significance of preprocedural cardiac troponin elevation among patients with stable coronary artery disease undergoing percutaneous coronary intervention: results from the evaluation of drug eluting stents and ischemic events registry. Circulation 2008;118(6):632-8

${ }^{34}$ Miller WL, Garratt KN, Burritt MF, Lennon RJ, Reeder GS, Jaffe AS. Baseline troponin level: key to understanding the importance of post-PCI troponin elevations. Eur Heart J 2006;27(9):10619

${ }^{35}$ White H. Avatar of the universal definition of periprocedural myocardial infarction. J Am Coll Cardiol 2013;62(17):1571-4 


\section{FIGURE LEGENDS}

Figure 1. Definition of periprocedural myocardial infarction related to different defintions and risk of MACE, after $771 \pm 332$ days. 
Table 1. Baseline feautures.

\begin{tabular}{|c|c|c|c|c|c|c|c|c|c|c|c|c|c|c|c|}
\hline \multirow[b]{2}{*}{ Age (years) } & \multicolumn{2}{|c|}{$\begin{array}{c}\text { Overall } \\
\text { Population } \\
n=712\end{array}$} & \multicolumn{2}{|c|}{$\begin{array}{c}\text { CK-MB > } 3 x \\
\text { URL MI } \\
n=48\end{array}$} & \multicolumn{2}{|c|}{$\begin{array}{c}\text { CK-MB > } 5 x \\
\text { URL MI } \\
n=22\end{array}$} & \multicolumn{2}{|c|}{$\begin{array}{l}\text { Tn }>3 x \\
99^{\text {th }} M l \\
n=254\end{array}$} & \multicolumn{2}{|c|}{$\begin{array}{l}\text { Tn }>5 x \\
99^{\text {th }} M I \\
n=190\end{array}$} & \multicolumn{2}{|c|}{$\begin{array}{l}2012 \text { Task } \\
\text { Force } \\
\text { definition } \\
\mathrm{n}=144\end{array}$} & \multicolumn{2}{|c|}{$\begin{array}{c}\text { SCAI } \\
\text { definition } \\
n=14\end{array}$} & \multirow{2}{*}{$\begin{array}{c}p \\
\\
\\
0.35 \\
0 \\
\end{array}$} \\
\hline & 68.9 & $\begin{array}{l} \pm \\
10.3 \\
\end{array}$ & 69.5 & $\begin{array}{l} \pm \\
9.2 \\
\end{array}$ & 69.8 & $\begin{array}{l} \pm \\
9.7 \\
\end{array}$ & 71.1 & $\begin{array}{l} \pm \\
9.8 \\
\end{array}$ & 71.4 & $\begin{array}{l} \pm \\
9.4 \\
\end{array}$ & 71.6 & $\begin{array}{l} \pm \\
9.5 \\
\end{array}$ & & $\begin{array}{l} \pm \\
8.8\end{array}$ & \\
\hline BMI & 24.6 & $\stackrel{ \pm}{8.8}$ & $24.7^{*}$ & \pm & 22.5 & $\begin{array}{l} \pm \\
10.0\end{array}$ & 24.4 & 8.6 & 24.1 & $\begin{array}{l} \pm \\
8.9\end{array}$ & 24.3 & $\frac{ \pm}{8.5}$ & & $\begin{array}{l} \pm \\
10 \\
2\end{array}$ & $\begin{array}{c}0.02 \\
3\end{array}$ \\
\hline LVEF (\%) & 55 & $\stackrel{ \pm}{9.9}$ & 54.7 & \pm & 56.5 & $\begin{array}{l} \pm \\
9.3\end{array}$ & 54.2 & $\begin{array}{l}10 . \\
6\end{array}$ & 54.4 & $\begin{array}{l} \pm \\
10 . \\
4\end{array}$ & 54.5 & $\stackrel{ \pm}{9.6}$ & $\begin{array}{l}55 . \\
8^{*}\end{array}$ & $\begin{array}{l} \pm \\
10 . \\
6\end{array}$ & $\begin{array}{c}< \\
0.00 \\
1\end{array}$ \\
\hline Gender (Male, n, \%) & 546 & 78.9 & 34 & 70.8 & 16 & 72.7 & 195 & $\begin{array}{l}79 . \\
9\end{array}$ & 142 & $\begin{array}{l}74 . \\
7\end{array}$ & 107 & 74.3 & 9 & $\begin{array}{l}64 . \\
3\end{array}$ & $\begin{array}{c}0.25 \\
3\end{array}$ \\
\hline Smoke (n, \%) & 385 & 54.1 & 28 & 58.3 & 12 & 54.5 & 134 & $\begin{array}{l}52 . \\
8\end{array}$ & 98 & $\begin{array}{l}51 . \\
6 \\
\end{array}$ & 80 & 55.6 & 7 & 50 & $\begin{array}{c}0.39 \\
7\end{array}$ \\
\hline Diabetes (n, \%) & 223 & 31.3 & 13 & 27.1 & 6 & 27.3 & 78 & $\begin{array}{l}30 \\
7\end{array}$ & 56 & $\begin{array}{l}29 . \\
5\end{array}$ & 40 & 27.8 & 3 & $\begin{array}{l}21 . \\
4\end{array}$ & $\begin{array}{c}0.45 \\
6\end{array}$ \\
\hline Hypertension (n, \%) & 552 & 77.5 & 40 & 83.3 & 19 & 86.4 & 200 & $\begin{array}{l}78 . \\
7\end{array}$ & 152 & 80 & 113 & 78.5 & & $\begin{array}{l}78 . \\
6\end{array}$ & $\begin{array}{c}0.06 \\
5\end{array}$ \\
\hline $\begin{array}{l}\text { Creatinine clearance } \\
(\mathrm{ml} / \mathrm{min})\end{array}$ & 66.2 & $\begin{array}{l} \pm \\
34.1\end{array}$ & 60.2 & \pm & 55.7 & 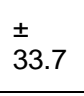 & 61 & $\begin{array}{l}34 . \\
5\end{array}$ & 59.6 & $\begin{array}{l}34 . \\
5\end{array}$ & 59.4 & 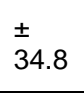 & $\begin{array}{l}53 . \\
5\end{array}$ & $\begin{array}{l} \pm \\
32 . \\
0\end{array}$ & $\begin{array}{c}0.07 \\
3\end{array}$ \\
\hline Stroke (n, \%) & 30 & 4.2 & 1 & 2.1 & 1 & 4.5 & 12 & 4.7 & 9 & 4.7 & 7 & 4.9 & 1 & 7.1 & $\begin{array}{c}0.46 \\
3\end{array}$ \\
\hline CABG (n, \%) & 90 & 12.6 & $11^{*}$ & 22.9 & 4 & 18.2 & 37 & $\begin{array}{l}14 . \\
6\end{array}$ & 27 & $\begin{array}{l}14 . \\
2\end{array}$ & 21 & 14.6 & 3 & $\begin{array}{l}21 . \\
4\end{array}$ & $\begin{array}{c}0.02 \\
5\end{array}$ \\
\hline Valvular disease $(\mathrm{n}, \%)$ & 82 & 11.5 & 7 & 14.6 & 4 & 18.2 & 33 & 13 & 25 & $\begin{array}{l}13 . \\
1\end{array}$ & 16 & 11.1 & 1 & 7.1 & $\begin{array}{c}0.29 \\
4\end{array}$ \\
\hline Diagnosis (n, \%) & & & & & & & & & & & & & & & $\begin{array}{c}0.08 \\
9\end{array}$ \\
\hline Unstable angina & 318 & 44.7 & 25 & 52.1 & 13 & 59.1 & 126 & $\begin{array}{l}49 . \\
6\end{array}$ & 96 & $\begin{array}{l}50 . \\
5\end{array}$ & 69 & 47.9 & 8 & $\begin{array}{l}57 . \\
1\end{array}$ & \\
\hline $\begin{array}{l}\text { Baseline elevated Troponin } \\
\text { levels(n, \%) }\end{array}$ & 72 & 10.1 & $12^{*}$ & 25 & $6^{*}$ & 27.3 & $50^{*}$ & $\begin{array}{l}19 . \\
7\end{array}$ & $46^{*}$ & $\begin{array}{l}24 . \\
2\end{array}$ & $36^{*}$ & 25 & 3 & $\begin{array}{l}21 . \\
4\end{array}$ & $\begin{array}{c}0.00 \\
5\end{array}$ \\
\hline Troponin peak (ng/l) & 0.13 & $\begin{array}{l} \pm \\
0.48\end{array}$ & $0.78^{*}$ & \pm & $1.33^{*}$ & $\stackrel{ \pm}{2.05}$ & $0.32^{*}$ & $\begin{array}{l} \pm \\
0.7 \\
4\end{array}$ & $\begin{array}{l}0.41 \\
*\end{array}$ & $\begin{array}{l} \pm \\
0.8 \\
4\end{array}$ & $\begin{array}{l}0.51 \\
*\end{array}$ & $\begin{array}{l} \pm \\
0.94\end{array}$ & $\begin{array}{l}2.1 \\
1^{*}\end{array}$ & $\begin{array}{l} \pm \\
2.4 \\
5 \\
\end{array}$ & $\begin{array}{c}< \\
0.00 \\
1\end{array}$ \\
\hline COPD (n.,\%) & 41 & 5.8 & $5^{\star}$ & 10.4 & $2^{*}$ & 9.1 & $17^{*}$ & 6.7 & $15^{\star}$ & 7.9 & $11^{*}$ & 7.6 & $1^{*}$ & 7.1 & $\begin{array}{c}<0.0 \\
01\end{array}$ \\
\hline TIMI flow (n, \%) & & & & & & & & & & & & & & & $\begin{array}{c}0.30 \\
5\end{array}$ \\
\hline 0 & 132 & 18.5 & 10 & 20.8 & 3 & 13.6 & 56 & 22 & 39 & $\begin{array}{l}20 . \\
5\end{array}$ & 28 & 19.4 & 3 & $\begin{array}{l}21 . \\
4\end{array}$ & \\
\hline 1 & 14 & 2 & 0 & & 0 & & 5 & 2 & 2 & 1.1 & 2 & 1.4 & 0 & & \\
\hline 2 & 56 & 7.9 & 4 & 8.3 & 3 & 13.6 & 18 & 7.1 & 15 & 7.9 & 14 & 9.7 & 0 & & \\
\hline 3 & 424 & 59.6 & 31 & 64.6 & 14 & 63.6 & 143 & $\begin{array}{l}56 . \\
3\end{array}$ & 107 & $\begin{array}{l}56 . \\
3\end{array}$ & 78 & 54.2 & 10 & $\begin{array}{l}71 . \\
4\end{array}$ & \\
\hline 3 vessel disease $(n, \%)$ & 217 & 30.5 & $24^{*}$ & 50 & $12^{*}$ & 54.5 & $97^{*}$ & $\begin{array}{l}38 . \\
2\end{array}$ & $77^{\star}$ & $\begin{array}{l}40 . \\
5\end{array}$ & $60^{*}$ & 41.7 & 7 & 50 & $\begin{array}{c}0.01 \\
4\end{array}$ \\
\hline 2 vessel disease $(n, \%)$ & 326 & 45.8 & 6 & 33.3 & $5^{*}$ & 22.7 & 116 & $\begin{array}{l}45 . \\
7\end{array}$ & 88 & $\begin{array}{l}46 . \\
3\end{array}$ & 64 & 44.4 & 3 & $\begin{array}{l}21 . \\
4\end{array}$ & $\begin{array}{c}0.02 \\
3\end{array}$ \\
\hline LM disease (n, \%) & 62 & 8.7 & 6 & 12.5 & 3 & 13.6 & 28 & 11 & 22 & $\begin{array}{l}11 . \\
6\end{array}$ & 18 & 12.5 & 2 & $\begin{array}{l}14 . \\
3\end{array}$ & $\begin{array}{c}0.05 \\
4\end{array}$ \\
\hline $\begin{array}{l}\text { Proximal LAD disease } \\
(\mathrm{n}, \%)\end{array}$ & 198 & 27.5 & 12 & 25 & 7 & 31.8 & 74 & $\begin{array}{l}29 . \\
1\end{array}$ & 59 & $\begin{array}{l}31 . \\
1\end{array}$ & 46 & 31.9 & 2 & $\begin{array}{l}14 . \\
3\end{array}$ & $\begin{array}{c}0.12 \\
5\end{array}$ \\
\hline Bifurcation (n, \%) & 146 & 20.4 & 12 & 25 & 7 & 31.8 & 60 & $\begin{array}{l}23 . \\
6\end{array}$ & $51^{*}$ & $\begin{array}{l}26 . \\
8\end{array}$ & 36 & 25 & 5 & $\begin{array}{l}35 . \\
7\end{array}$ & $\begin{array}{c}0.00 \\
8\end{array}$ \\
\hline CTO (n, \%) & 169 & 23.7 & 14 & 29.2 & 6 & 27.3 & $78^{*}$ & $\begin{array}{l}30 . \\
7\end{array}$ & $58^{*}$ & $\begin{array}{l}30 . \\
5\end{array}$ & $47^{*}$ & 32.6 & 5 & $\begin{array}{l}35 . \\
7\end{array}$ & $\begin{array}{c}0.01 \\
5\end{array}$ \\
\hline $\begin{array}{l}\text { Rotational Atherectomy (n, } \\
\% \text { ) }\end{array}$ & 14 & 2 & 1 & 2.1 & 1 & 4.5 & $9^{*}$ & 3.5 & $8^{*}$ & 4.2 & $6^{*}$ & 4.2 & 1 & 7.1 & $\begin{array}{c}0.03 \\
7\end{array}$ \\
\hline
\end{tabular}

* marks the groups with statistically significant differences 
MI, myocardial infarction; BMI, body mass index; LVEF, left ventricular ejection fraction; CABG, coronary artery by-pass graft; ICD, implantable cardioverter defibrillator, COPD, chronic obstructive pulmonary disease; LM, left main coronary; LAD, left anterior descending coronary; CTO, chronic total occlusion. 
Table 2. Events at follow up according to different definitions of periprocedural myocardial infarction.

\begin{tabular}{|c|c|c|c|c|c|c|c|c|c|c|c|c|c|c|}
\hline \multirow[b]{2}{*}{ Follow up (days) } & \multicolumn{2}{|c|}{$\begin{array}{l}\text { Overall } \\
\text { Population } \\
\mathrm{n}=712\end{array}$} & \multicolumn{2}{|c|}{$\begin{array}{c}\text { CK-MB > } 3 x \\
\text { URL MI } \\
\mathrm{n}=48\end{array}$} & \multicolumn{2}{|c|}{$\begin{array}{c}\text { CK-MB }>5 \times \text { URL } \\
\text { MI } \\
\mathrm{n}=22\end{array}$} & \multicolumn{2}{|c|}{$\begin{array}{c}\mathrm{Tn}>3 \times 99^{\text {th }} \mathrm{Ml} \\
\mathrm{n}=254\end{array}$} & \multicolumn{2}{|c|}{$\begin{array}{c}\mathrm{Tn}>5 \times 99^{\text {th }} \mathrm{Ml} \\
\mathrm{n}=190\end{array}$} & \multicolumn{2}{|c|}{$\begin{array}{l}2012 \text { Task } \\
\text { Force definition } \\
\qquad \mathrm{n}=144\end{array}$} & \multicolumn{2}{|c|}{$\begin{array}{c}\text { SCAI } \\
\text { definition } \\
\mathrm{n}=14\end{array}$} \\
\hline & 771 & \pm 332 & 809 & \pm 269 & 792 & \pm 241 & 783 & \pm 332 & 759 & \pm 333 & 770 & \pm 334 & 749 & $\underset{288}{ \pm}$ \\
\hline MACE $(n, \%)$ & 115 & 16.7 & 8 & 16.7 & 3 & 13.6 & 47 & 18.8 & 31 & 16.7 & 21 & 14.9 & 4 & 28.6 \\
\hline Death $(n, \%)$ & 35 & 5.1 & 1 & 2.2 & 0 & & 15 & 6.2 & 11 & 6.1 & 9 & 6.7 & 1 & 7.7 \\
\hline \multicolumn{15}{|c|}{ Type of death (n, \%) } \\
\hline Non-CV & 10 & 1.5 & 1 & 2.2 & 0 & & 2 & 0.8 & 2 & 1.1 & 2 & 1.5 & 0 & \\
\hline CV AMI & 15 & 2.2 & 0 & & 0 & & 6 & 2.5 & 4 & 2.2 & 4 & 3.0 & 1 & 7.7 \\
\hline CV HF & 9 & 1.3 & 0 & & 0 & & 6 & 2.5 & 4 & 2.2 & 2 & 1.5 & 0 & \\
\hline $\operatorname{AMI}(n, \%)$ & 18 & 2.6 & 1 & 2.1 & 0 & & 7 & 2.8 & 6 & 3.2 & 3 & 2.1 & 0 & \\
\hline $\operatorname{rePCl}(n, \%)$ & 83 & 12.0 & 7 & 15.6 & 3 & 14.3 & 31 & 12.8 & 23 & 12.8 & 16 & 11.9 & 3 & 23.1 \\
\hline $\mathrm{CABG}(\mathrm{n}, \%)$ & 3 & 0.4 & 0 & & 0 & & 1 & 1.5 & 0 & & 0 & & 0 & \\
\hline
\end{tabular}

MI, myocardial infarction; Non-CV, non cardiovascular death; CV AMI, cardiovascular death due to myocardial infarction; CV HF, cardiovascular death due to heart failure; AMI, acute myocardial infarction; rePCl, repeated percutaneous coronary intervention; CABG, coronary artery by-pass graft. 
Table 3. Univariate predictors of MACE and its single components

\begin{tabular}{|c|c|c|c|c|c|c|c|}
\hline MACE & $\mathrm{p}$ & Death & $\mathrm{p}$ & AMI & $\mathrm{p}$ & rePCl & $\mathrm{p}$ \\
\hline Age & 0.041 & Age & $<0.001$ & Diabetes & 0.037 & Sex & 0.037 \\
\hline $\begin{array}{l}\text { Cretinine } \\
\text { clearance }\end{array}$ & 0.049 & $\begin{array}{l}\text { Creatinine } \\
\text { clearance }\end{array}$ & 0.001 & & & Diabetes & 0.002 \\
\hline LVEF & 0.025 & LVEF & 0.008 & & & $\begin{array}{l}3 \text { vessel } \\
\text { disease }\end{array}$ & 0.002 \\
\hline Diabetes & 0.01 & COPD & $<0.001$ & & & LM disease & 0.016 \\
\hline $\begin{array}{l}\text { Valvular } \\
\text { disease }\end{array}$ & 0.005 & Stroke & 0.044 & & & СТО & $<0.001$ \\
\hline $\begin{array}{l}\text { Baseline } \\
\text { elevated } \\
\text { Troponin levels }\end{array}$ & 0.023 & $\begin{array}{l}\text { Valvular } \\
\text { disease }\end{array}$ & $<0.001$ & & & $\begin{array}{l}\text { Euro Heart PCl } \\
\text { score }\end{array}$ & 0.028 \\
\hline LM disease & 0.012 & C type lesion & 0.017 & & & & \\
\hline СТО & 0.012 & $\begin{array}{l}\text { Euro Heart PCl } \\
\text { score }\end{array}$ & $<0.001$ & & & & \\
\hline $\begin{array}{l}\text { Euro Heart PCI } \\
\text { score }\end{array}$ & 0.004 & & & & & & \\
\hline
\end{tabular}

AMI, acute myocardial infarction; rePCI, repeated percutaneous coronary intervention; LVEF, left ventricular ejection fraction; LM, left main coronary; CTO, chronic total occlusion; COPD, chronic obstructive pulmonary disease. 
Table 4. Cox proportional hazards analysis testing independent predictors of MACE.

Six different models were run, each for every different PCl-related myocardial infarction.

\begin{tabular}{|lccc|}
\hline & OR & $95 \% \mathrm{Cl}$ & $\mathrm{p}$ \\
\hline Age & 1.022 & $0.992-1.053$ & 0.148 \\
Creatinine clearance & 1.002 & $0.992-1.011$ & 0.746 \\
LVEF & 0.990 & $0.969-1.011$ & 0.354 \\
Diabetes & 1.164 & $0.734-1.847$ & 0.519 \\
Valvular disease & 1.987 & $1.103-3.580$ & 0.022 \\
Baseline elevated Troponin levels & 0.301 & $0.110-0.829$ & 0.020 \\
LM disease & 1.240 & $0.651-2.362$ & 0.512 \\
CTO & 1.308 & $0.838-2.040$ & 0.237 \\
Euro Heart PCI score & 1.014 & $0.961-1.071$ & 0.607 \\
CK-MB > 3 URL MI & 0.915 & $0.413-2.025$ & 0.827 \\
CK-MB > 5 URL MI & 0.831 & $0.201-3.444$ & 0.799 \\
Tn $>3 \times 99^{\text {th }}$ MI & 0.897 & $0.570-1.411$ & 0.638 \\
Tn $>5 \times 99^{\text {th }}$ MI & 0.961 & $0.592-1.563$ & 0.874 \\
2012 Task Force definition & 0.855 & $0.493-1.484$ & 0.578 \\
SCAI definition & 2.830 & $0.876-9.144$ & 0.082 \\
\hline
\end{tabular}

LVEF, left ventricular ejection fraction; LM, left main coronary; CTO, chronic total occlusion; MI, myocardial infarction. 
Table 5. Area Under the Curve (AUC) for different definitions for MACE.

\begin{tabular}{|l|c|c|c|c|c|c|}
\hline & AUC & LCI & UCI & $\begin{array}{c}\text { Hosmer- } \\
\text { lemeshow test }\end{array}$ & $\mathbf{R}^{2}$ of Nagelkerke & AIC \\
\hline CK-MB $>3 \times$ URL MI & 0.50 & 0.44 & 0.55 & 0.79 & 0.11 & 511 \\
\hline CK-MB $>5 \times$ URL MI & 0.49 & 0.43 & 0.55 & 0.78 & 0.11 & 512 \\
\hline Tn $>3 \times 99^{\text {th }}$ MI & 0.53 & 0.46 & 0.58 & 0.70 & 0.10 & 500 \\
\hline Tn $>5 \times 99^{\text {th }}$ MI & 0.51 & 0.44 & 0.56 & 0.11 & 0.12 & 509 \\
\hline 2012 Task Force definition & 0.48 & 0.43 & 0.56 & 0.08 & 0.11 & 510 \\
\hline SCAI definition & 0.48 & 0.43 & 0.55 & 0.81 & & \\
\hline
\end{tabular}

